\title{
Comparison of shortened and conventional dry period management strategies
}

\author{
J. Cermakova, ${ }^{\star 1}$ V. Kudrna, ${ }^{*}$ M. Simeckova, ${ }^{*}$ A. Vyborna, ${ }^{*}$ P. Dolezal, $\dagger$ and J. Illek* \\ *Institute of Animal Science, 10400 Praha Uhrineves, Czech Republic \\ †Mendel University in Brno, 61300 Brno, Czech Republic
}

\begin{abstract}
The aim of this study was to compare 2 dry-cow management strategies and evaluate the effect of shortened dry period strategy on feed intake, metabolism, and postpartum performance of dairy cows in early lactation. Twenty-nine high-yielding dairy cows were divided into 2 groups. The control (CON) group (n $=14$ ) was assigned to a traditional dry period of approximately $60 \mathrm{~d}(57 \pm 5.9 \mathrm{~d})$ and was fed a far-off dry cow ration from dry-off to $-21 \mathrm{~d}$ relative to expected parturition. From d -21 relative to expected parturition, the cows were switched to a precalving ration containing an additional $3 \mathrm{~kg}$ of concentrates. The cows of the experimental group $(\mathrm{n}=15)$ were assigned to a shortened dry period (SDP; $35 \pm 6.3 \mathrm{~d}$ ) and were continuously fed a late-lactation diet from $\mathrm{d}-60 \mathrm{~d}$ relative to expected parturition until calving. After calving, both groups were fed the same lactation diet corresponding to their lactation requirements and cows were followed for $100 \mathrm{~d}$ of lactation. Prepartum dry matter intake of the cows assigned to an SDP and fed a late-lactation diet was approximately $4.11 \mathrm{~kg} / \mathrm{cow}$ per day greater compared with the CON group during the $60 \mathrm{~d}$. However, no effect of dry period strategy on postpartum dry matter intake was detected. The cows with an SDP produced approximately $2.78 \mathrm{~kg} / \mathrm{d}$ $(6.9 \%)$ less milk in the first $100 \mathrm{~d}$ of lactation than CON cows; the difference was not statistically significant. No differences were observed in live body weight, body condition score, or back-fat thickness between the treatments. Similarly, no differences existed in concentrations of plasma metabolites. The cows of the SDP group showed lower $\mathrm{pH}$ and increased concentrations of lactic acid and volatile fatty acids prepartum than the CON cows. Postpartum concentrations of lactic acid, volatile fatty acids, and $\mathrm{NH}_{3}$ and $\mathrm{pH}$ in rumen fluid did not differ between the treatments. Shortening of the dry period did not affect the colostrum quality or birth
\end{abstract}

Received September 19, 2013

Accepted May 25, 2014.

${ }^{1}$ Corresponding author: cermakova.jana@vuzv.cz weights of the calves. Based on the results of this study, a traditional dry period management strategy appeared to be more favorable, considering the dry matter intake and milk production, compared with an SDP and feeding a late-lactation diet throughout the dry period.

Key words: nutrition, transition period, milk production, metabolic status

\section{INTRODUCTION}

Intensive genetic selection for productivity has resulted in a dramatic increase in milk production in modern high-yielding dairy cows. However, as milk production per cow has increased, transitioning cows from the nonlactating state to peak milk yield has grown more problematic. In general, high milk energy output in early lactation has not been matched with appropriate energy intake. The transition period is the most difficult period in the dairy cow life cycle and is accompanied by decreased DMI, whereas milk production increases in early lactation (Bertics et al., 1992; Hayirli et al., 2002). An energy deficit results in a negative energy balance (NEB) and loss of BW, body condition, and body fat reserves. Severe NEB negatively affects immune and reproductive functions, resulting in an increased culling rate. Therefore, it is appropriate to evaluate alternative management and feeding strategies for the dry and transition periods to reduce the magnitude of the NEB.

Traditionally, cows are dried off approximately $60 \mathrm{~d}$ before expected calving. They are fed a far-off dry cow ration based on roughage from dry-off to $21 \mathrm{~d}$ prepartum and are then switched to a close-up diet enriched by the addition of concentrate mixture (Hutjens, 1996; Degaris et al., 2008). The gradual addition of concentrates in the last $3 \mathrm{wk}$ of pregnancy allows rumen bacteria to adapt to a lactation diet rich in concentrates to facilitate high milk production in early lactation. The NRC (2001) suggests that the required energy concentrations in the diet of dried-off cows are $4.061 \mathrm{MJ} / \mathrm{kg}$ of DM at $240 \mathrm{~d}$ of pregnancy, $4.396 \mathrm{MJ} / \mathrm{kg}$ of $\mathrm{DM}$ at $270 \mathrm{~d}$ of pregnancy, and $6.029 \mathrm{MJ} / \mathrm{kg}$ of DM at $279 \mathrm{~d}$ of pregnancy, and the required dietary MP concentrations 
are $6.0 \%$ at $240 \mathrm{~d}$ of pregnancy, $6.6 \%$ at $270 \mathrm{~d}$ of pregnancy, and $8.0 \%$ at $279 \mathrm{~d}$ of pregnancy. To transition a cow during the last weeks of gestation to acclimate her to a lactating ration, NRC (2001) recommends a standard close-up diet with an energy concentration of approximately $6.741 \mathrm{MJ} / \mathrm{kg}$ and a dietary MP concentration of $8.5 \%$.

A dry period of 40 to $60 \mathrm{~d}$ facilitates the proliferation of mammary cells to maximize milk, fat, and protein yields in the next lactation (Capuco et al., 1997; Kuhn et al., 2005; Sawa et al., 2012). However, recent research has indicated that shortening or even omitting the dry period seems to shift milk production from the critical period shortly after calving to the weeks before calving, when the energy demands of the mammary glands for milk production can be easily matched by feed intake (Weber et al., 2013; Wiedemann et al., 2013). Moreover, short-dry-period management requires less abrupt changes in diet composition and may result in a more sustained level of feed intake, which is beneficial for the energy status (Rastani et al., 2005; Mantovani et al., 2010b) and may increase milk and milk component yields and improve the health and fertility of dairy cows during early lactation (Klusmeyer et al., 2009; O'Driscoll et al., 2012; McArt et al., 2013). In contrast, the potential risks of a reduced dry period include reduction in milk yield in subsequent lactation (Sørensen and Enevoldsen, 1991; Annen et al., 2004; Rastani et al., 2005), impaired udder health (e.g., higher milk SCC and increased mastitis incidence; Enevoldsen and Sørensen, 1992; Kuhn et al., 2006; Whist et al., 2006), and reduced colostrum quality, potentially affecting calf health (Annen et al., 2004; Rastani et al., 2005; Klusmeyer et al., 2009).

The present study compares traditional (60-d) and shortened (35-d) dry period (SDP) management strategies to evaluate their effects on DMI, milk production, body condition, metabolic status, colostrum quality, and birth weight (BiW) of the calves. The hypothesis was that shortening the dry period combined with feeding a late-lactation diet would be more beneficial, considering the DMI, milk production and other parameters, compared with the conventional dry period of $60 \mathrm{~d}$ and feeding a far-off and close-up dry-cow diet.

\section{MATERIALS AND METHODS}

\section{Experimental Design, Animals, and Diets}

The experiment included 29 high-yielding dairy cows, which were divided into 2 groups according to breed, parity, milk yield in the previous lactation, and live BW. There were 14 cows (12 Holstein-Friesian and 2 Czech Fleckvieh) in the control (CON) group and 15 cows (13 Holstein-Friesian and 2 Czech Fleckvieh) in the experimental group (SDP). Mean milk yield in the previous lactation (mean $=299 \mathrm{~d})$ was $9,088 \mathrm{~kg}(\mathrm{SD}=$ $2,061 \mathrm{~kg}$ ) for the CON group and 8,801 $\mathrm{kg}(\mathrm{SD}=2,189$ $\mathrm{kg}$ ) for the SDP group. There were 7 primiparous and 7 multiparous (parities 1-3) cows in the CON group and 8 primiparous and 7 multiparous (parities $1-4$ ) cows in the SDP group. Mean BW was $618 \mathrm{~kg}(\mathrm{SD}=76 \mathrm{~kg})$ for the CON group and $596 \mathrm{~kg}(\mathrm{SD}=69 \mathrm{~kg})$ for the SDP group.

Cows were housed in a freestall stable with beds littered with straw, and they were followed from $-60 \mathrm{~d}$ precalving to d 100 of lactation. The diets were based on maize silage, lucerne silage, lucerne hay, ensiled crushed maize cobs with bracts, fresh brewer grains, and concentrate mixture. The ingredient composition of the diets is reported in Table 1 . Table 2 shows the composition of the concentrate mixtures included in the diets. The diets were formulated according to NRC (2001) guidelines and fed in the form of TMR ad libitum. The CON group, assigned to the conventional dry period of $57 \mathrm{~d}(\mathrm{SD}=5.9 \mathrm{~d})$, was fed a far-off dry cow ration (TMRD) from dry-off to $21 \mathrm{~d}$ prepartum. Approximately $21 \mathrm{~d}$ before planned calving, the concentrate mixture $(3 \mathrm{~kg} / \mathrm{d})$ was added to their diet. The SDP group, assigned to an SDP of $35 \mathrm{~d}(\mathrm{SD}=6.3 \mathrm{~d})$, was continuously fed a late-lactation diet (TMR2) from d -60 to calving. After calving, all cows in both groups were fed TMR2 first $7 \mathrm{~d}$ postpartum and the early-lactation diet from d 8 to 100 of lactation, corresponding to their lactation requirements.

\section{Measurements, Sampling Procedures, Analytical Methods, Calculations, and Estimates}

Cows were equipped with electronic identification chips to allow automatic measurement of their feed intake. Intake was recorded electronically by software using the automatic feeding system of Insentec BV (Marknesse, the Netherlands) with troughs on tensometric scales. Once per month, samples of feed (both TMR and ingredients) were taken. Dry matter content was determined by drying samples of feed at $102 \pm 3{ }^{\circ} \mathrm{C}$ to a constant weight immediately after their collection. The standard AOAC International (2005) procedures were used to determine the content of $\mathrm{CP}$, crude fat, starch, and ash in the feed. Crude protein content $(6.25 \times \mathrm{N})$ was determined using a Kjeltec 1030 Auto Analyzer (Foss Tecator AB, Höganäs, Sweden), and crude fat content was determined with a Soxtec 1043 extraction system (FOSS Tecator AB). Mineral element (i.e., $\mathrm{Ca}, \mathrm{K}, \mathrm{Mg}$, and $\mathrm{Na}$ ) concentrations were determined by atomic absorption spectrometry (Solaar M-6; TJA Solutions Ltd., Northampton, UK), and the 
Table 1. Ingredients of diets ( $\mathrm{g} / \mathrm{kg}$ of DM, unless otherwise specified) for cows with conventional (control, $\mathrm{CON})$ and shortened dry periods (SDP)

\begin{tabular}{|c|c|c|c|c|}
\hline \multirow[b]{2}{*}{ Component } & \multicolumn{4}{|c|}{$\operatorname{Diet}^{1}$} \\
\hline & TMR1 & TMR2 & TMRD & TMRDC \\
\hline \multicolumn{5}{|l|}{ Ingredient } \\
\hline Maize silage & 521 & 385 & 435 & 431 \\
\hline Lucerne silage & 521 & 446 & 399 & 395 \\
\hline Ensiled crushed maize cobs with bracts & 223 & 182 & 0 & 0 \\
\hline Legume-cereal silage & 0 & 425 & 762 & 754 \\
\hline Lucerne hay & 37 & 24 & 145 & 144 \\
\hline Brewers grain & 298 & 243 & 0 & 0 \\
\hline Wheat straw & 30 & 0 & 36 & 36 \\
\hline Energie $\mathrm{MG}^{2}$ & 37 & 20 & 0 & 0 \\
\hline $\mathrm{DO}^{3}$ & 342 & 0 & 0 & 215 \\
\hline $\mathrm{DO} 2^{3}$ & 0 & 284 & 0 & 0 \\
\hline Premin EX $28^{4}$ & 0 & 0 & 15 & 14 \\
\hline Premin Porod ${ }^{5}$ & 0 & 0 & 0 & 22 \\
\hline \multicolumn{5}{|l|}{ Chemical analysis } \\
\hline $\mathrm{DM}(\mathrm{g} / \mathrm{kg})$ & 497.66 & 466.42 & 430.75 & 475.10 \\
\hline $\mathrm{CP}$ & 176.96 & 170.99 & 140.17 & 164.16 \\
\hline Crude fat & 46.14 & 31.43 & 18.39 & 30.78 \\
\hline Crude fiber & 179.78 & 192.81 & 291.40 & 243.66 \\
\hline Starch & 184.91 & 175.02 & 51.62 & 99.35 \\
\hline $\mathrm{PDIA}^{6}$ & 64.81 & 58.06 & 44.57 & 57.14 \\
\hline $\mathrm{PDIE}^{7}$ & 105.00 & 98.91 & 78.69 & 93.64 \\
\hline $\mathrm{PDIN}^{8}$ & 115.06 & 108.50 & 83.36 & 103.24 \\
\hline $\mathrm{NE}_{\mathrm{L}}(\mathrm{MJ} / \mathrm{kg}$ of $\mathrm{DM})$ & 6.66 & 6.33 & 5.49 & 5.94 \\
\hline $\mathrm{ADF}$ & 230.63 & 247.80 & 354.05 & 300.86 \\
\hline NDF & 371.91 & 394.54 & 486.87 & 432.76 \\
\hline Ash & 82.48 & 79.83 & 86.43 & 90.95 \\
\hline $\mathrm{Ca}$ & 11.46 & 12.23 & 12.62 & 13.66 \\
\hline $\mathrm{P}$ & 4.12 & 4.39 & 2.65 & 3.80 \\
\hline $\mathrm{Na}$ & 3.14 & 3.35 & 1.56 & 2.66 \\
\hline K & 14.08 & 15.03 & 15.95 & 14.94 \\
\hline $\mathrm{Mg}$ & 3.53 & 3.77 & 2.81 & 3.38 \\
\hline
\end{tabular}

${ }^{1}$ TMR1 = early-lactation diet fed from d 8 to 100 postpartum for both CON and SDP groups; TMR2 = latelactation diet fed from $d-60$ relative to expected calving until calving (d 0) for the SDP group, and from $d 1$ to 7 postpartum in both CON and SDP groups; TMRD = far-off dry cow diet fed from $\mathrm{d}-60$ to -21 relative to expected parturition for the CON group; TMRDC = precalving diet fed from $\mathrm{d}-21$ relative to expected parturition until calving (d 0) for the CON group.

${ }^{2}$ Commodity Trading s.r.o. (Olomouc, Czech Republic); contained 50\% glycerol and 50\% molasses.

${ }^{3} \mathrm{DO} 1=$ concentrate mixture in the feed ration TMR1 and TNRDC; DO2 = concentrate mixture in the feed ration TMR2.

${ }^{4}$ VVS Verměřovice, s.r.o., (Verměřovice, Czech Republic); contained per $1 \mathrm{~kg}: 10 \mathrm{~g}$ of Ca, $100 \mathrm{~g}$ of P, $50 \mathrm{~g}$ of $\mathrm{Mg}$, $60 \mathrm{~g}$ of $\mathrm{Na}, 1,300 \mathrm{mg}$ of $\mathrm{Cu}, 6,000 \mathrm{mg}$ of Zn, 9,000 $\mathrm{mg}$ of Mn, $40 \mathrm{mg}$ of Co, $100 \mathrm{mg}$ of I, $35 \mathrm{mg}$ of Se, 900,000 IU of vitamin A, 120,000 IU of vitamin $\mathrm{D}_{3}$, and 3,000 $\mathrm{mg}$ of vitamin $\mathrm{E}$.

${ }^{5}$ VVS Verměřovice s.r.o.; contained per $1 \mathrm{~kg}$ : $100 \mathrm{~g}$ of $\mathrm{Ca}, 20 \mathrm{~g}$ of P, $25 \mathrm{~g}$ of $\mathrm{Mg}, 25 \mathrm{~g}$ of Na, $500 \mathrm{mg}$ of $\mathrm{Cu}$, 2,500 $\mathrm{mg}$ of Zn, 2,000 $\mathrm{mg}$ of Mn, $10 \mathrm{mg}$ of Co, $60 \mathrm{mg}$ of I, $10 \mathrm{mg}$ of Se, 200,000 IU of vitamin A, 41,000 IU of vitamin $\mathrm{D}_{3}$, and $1,000 \mathrm{mg}$ of vitamin $\mathrm{E}$.

${ }^{6}$ Ruminally undegraded feed protein digested in the small intestine.

${ }^{7}$ Metabolizable protein supply.

${ }^{8}$ Ruminally degradable nitrogen.

$\mathrm{P}$ concentration was determined photometrically [Spekol 11 spectrophotometer (Analytik Jena AG, Jena, Germany); ISO, 2005].

Cows were milked twice daily, once between 0430 and $0515 \mathrm{~h}$ and once between 1630 and $1715 \mathrm{~h}$, through a 10-point side open (tandem) parlor. Calved cows were followed for 100 DIM. Milk yield was recorded automatically at each milking for each animal and mean daily milk yield was calculated. In addition, the data from the milk control records were obtained to analyze milk yields for standardized lactation (305 d). Blended milk samples from 2 consecutive collections (a.m. and p.m.) were taken from each cow with intervals of $14 \mathrm{~d}$ through first 100 DIM and were pooled for determination of fat, protein, lactose, and urea. In addition, blended milk samples from SDP cows were taken at d -60 and -40 before planned calving. The milk was preserved with 2-bromo-2-nitropropane-1,3-diol and cooled 
Table 2. Composition of concentrate mixtures

\begin{tabular}{lrc}
\hline $\begin{array}{l}\text { Ingredient } \\
\text { (g/kg of DM) }\end{array}$ & $\mathrm{DO}^{1}$ & $\mathrm{DO}^{2}$ \\
\hline Wheat & 215 & 265 \\
Barley & 0 & 210 \\
Rapeseed meal & 145 & 200 \\
Soybean meal & 170 & 145 \\
Triticale & 180 & 0 \\
Pea meal & 0 & 100 \\
Lupine seed & 85 & 0 \\
Premin DO1 $^{3}$ & 80 & 0 \\
Premin DO2 & 45 \\
Soda bicarbonate $^{5}$ & 0 & 60 \\
Aminoplus $^{5}$ & 0 & 20 \\
C16 Lodestar $^{6}$ & 80 & 0 \\
\hline
\end{tabular}

${ }^{1}$ Concentrate mixture in the early-lactation diet fed from d 8 to 100 postpartum (TMR1) and in the precalving diet fed from $\mathrm{d}-21$ relative to expected parturition until calving (d 0) for the control (CON) group (TMRDC).

${ }^{2}$ Concentrate mixture in the late-lactation diet fed from $\mathrm{d}-60$ relative to expected calving until calving (d 0 ) for the shortened dry perioc (SDP) group, and from d 1 to 7 postpartum in both CON and SDP groups (TMR2).

${ }^{3}$ VVS Verměřovice s.r.o. (Verměřovice, Czech Republic); contained per $1 \mathrm{~kg}: 127 \mathrm{~g}$ of CP, $133 \mathrm{~g}$ of $\mathrm{Ca}, 33 \mathrm{~g}$ of P, $40 \mathrm{~g}$ of $\mathrm{Mg}, 52 \mathrm{~g}$ of Na, 630 $\mathrm{mg}$ of $\mathrm{Cu}, 3,160 \mathrm{mg}$ of $\mathrm{Zn}, 4,860 \mathrm{mg}$ of $\mathrm{Mn}, 21 \mathrm{mg}$ of Co, $53 \mathrm{mg}$ of I, $18 \mathrm{mg}$ of Se, 403,000 IU of vitamin A, 73,500 IU of vitamin $\mathrm{D}_{3}, 1,200$ $\mathrm{mg}$ of vitamin $\mathrm{E}$, and 4,700 $\mathrm{mg}$ of niacinamide.

${ }^{4}$ VVS Verměřovice; contained per $1 \mathrm{~kg}$ : $175 \mathrm{~g}$ of $\mathrm{Ca}, 31 \mathrm{~g}$ of $\mathrm{P}, 43 \mathrm{~g}$ of $\mathrm{Mg}, 91 \mathrm{~g}$ of $\mathrm{Na}, 1,000 \mathrm{mg}$ of $\mathrm{Cu}, 5,300 \mathrm{mg}$ of $\mathrm{Zn}, 4,860 \mathrm{mg}$ of $\mathrm{Mn}, 20$ $\mathrm{mg}$ of Co, $47 \mathrm{mg}$ of I, $27 \mathrm{mg}$ of Se, 667,000 IU of vitamin A, 86,500 IU of vitamin $\mathrm{D}_{3}$, and $1,440 \mathrm{mg}$ of vitamin $\mathrm{E}$.

${ }^{5} \mathrm{Ag}$ Processing Inc. (Omaha, NE); rumen-undegradable protein.

${ }^{6}$ Berg + Schmidt Malaysia Sdn. Bhd. (Selangor Darul Ehsan, Malaysia); rumen-protected fat.

to 4 to $6{ }^{\circ} \mathrm{C}$ until analysis. Milk components were analyzed in a commercial laboratory using a MilkoScan FT 2 instrument (Foss Electric A/S, Hillerød, Denmark). Milk urea concentration was determined enzymatically using the Urea/Ammonia Assay Kit (Megazyme International Ireland, Bray, Co. Wicklow, Ireland). Somatic cell count data were obtained from milk production control records. Somatic cell count was transformed to linear score (LS) using the following formula: LS = $\left.\log _{\mathrm{e}}(\mathrm{SCC}) / 0.6931\right)-3.6439$, where SCC is the SCC in thousands per milliliter (Schukken et al., 2009). Fatcorrected milk (containing 4\% fat) yield was calculated as follows: FCM $(\mathrm{kg} / \mathrm{d})=$ milk yield $(\mathrm{kg}) \times[0.4+$ $0.15 \times$ fat $(\%)$ ]. Energy-corrected milk (containing $4 \%$ fat and $3.4 \%$ protein) yield was calculated as follows: $\mathrm{ECM}(\mathrm{kg} / \mathrm{d})=$ milk yield $(\mathrm{kg}) \times[0.25+0.122 \times$ fat $(\%)+0.077 \times$ protein $(\%)]$. The relative changes in milk fat, milk protein, lactose, and urea concentrations in the first 100 DIM were calculated as the average per group (SDP or $\mathrm{CON}$ ) at selected sampling days (i.e., $14,28,42,56,70,84$, and $98 \mathrm{~d}$ postpartum). The BW was measured automatically at each milking. Dried-off cows were weighed every $14 \mathrm{~d}$. The BCS was evaluated every $14 \mathrm{~d}$ from $\mathrm{d}-60$ before calving until the end of the experiment (100 DIM) by the same assessor, using a scale from 1 to 5 with 0.25 -point increments (Edmonson et al., 1989). Along with the evaluation of BCS, back-fat thickness (BFT) was measured in the pelvic area dorsal to the hip joint (Schröder and Staufenbiel, 2006), using the ultrasound apparatus SonoVet 2000 (Samsung Medison Co. Ltd., Seoul, South Korea), with a linear probe (L2-5/170CD) at 5.5 MHz.

Blood samples were obtained from the coccygeal vein at $0900 \mathrm{~h}$ and samples of rumen fluid were taken using a probe at $\mathrm{d}-60,-25$, and -7 relative to expected parturition and at $\mathrm{d} 3,10$ and 25 relative to calving. Blood was collected into heparinized plasma tubes. Immediately after their collection, all tubes were centrifuged at $797 \times g$ for $20 \mathrm{~min}$ at room temperature $\left(\sim 20^{\circ} \mathrm{C}\right)$. Blood plasma after centrifugation was divided into 3 aliquots and stored at $-18^{\circ} \mathrm{C}$ until analysis. Blood plasma was analyzed in a commercial laboratory Veterinary laboratory (VLAB, Brno, Czech Republic) on an automatic analyzer (Roche Hitachi; Randox Laboratories Ltd., Crumlin, UK) using set $\mathrm{f}$. Hormones were determined by the immunofluorescence technique on the Immulite apparatus (Siemens Medical Solutions Diagnostics, Los Angeles, CA). Samples of rumen fluid were obtained using a probe and preserved with $1 \mathrm{~mL}$ of ethanol until immediate analysis after their collection in a commercial laboratory (Institute of Animal Science, Prague Uhrineves, Czech Republic) on an Ionosep 2003 isotachophoretic analyzer (Recman Laboratory Systems, Ostrava-Hrabůvka, Czech Republic).

Colostrum IgG concentrations were measured on the first milking with a colostrodoser and the values were adjusted to the concentrations of $\operatorname{IgG}$ at $20^{\circ} \mathrm{C}$. The $\mathrm{BiW}$ of calves were measured at the time they were moved into individual pens, approximately $2 \mathrm{~h}$ after calving.

\section{Statistical Analyses}

Data were statistically analyzed using SAS software (version 9.1; SAS Institute Inc., Cary, NC). Precalving and postcalving data were analyzed separately. Milk production data were analyzed using a linear model with 3 fixed effects: 2 dichotomous (group and parity) and 1 continuous (previous lactation). The values for the CON or SDP level were estimated using the LSMEANS function. Concentrations of plasma metabolites and parameters of rumen fluid were analyzed using a linear model with 2 dichotomous fixed effects (group and parity); DMI, BW, BCS, BFT, colostral IgG concentrations, and $\mathrm{BiW}$ were tested by the $t$-test. Stillborn calves $(n=2)$ and twins $(n=3)$ were excluded from the statistical analysis of BiW. 
Table 3. Least squares means for DMI, BW, BCS, back fat thickness (BFT), concentrations of colostrum IgG, birth weights (BiW) of calves, milk yield, and milk content in the first $100 \mathrm{~d}$ of lactation for cows assigned to conventional (control, CON) or shortened dry periods (SDP) in the first $100 \mathrm{DIM}^{1}$

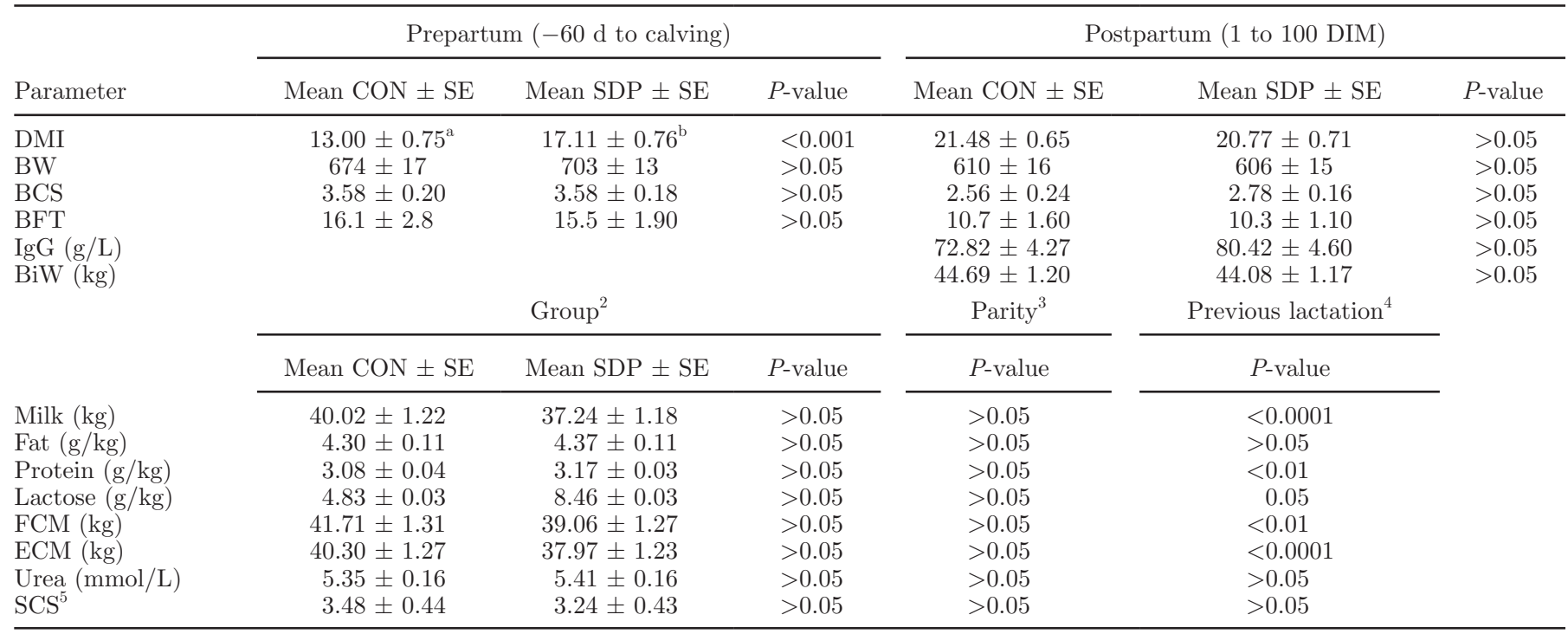

${ }^{\mathrm{a}, \mathrm{b}}$ Means within a row with different superscript letters differ $(P<0.05)$.

${ }^{1}$ The milk production data were analyzed using a linear model with 3 fixed effects: 2 dichotomous (group and parity) and 1 continuous (previous lactation). The values for the CON or SDP level were estimated using the LSMEANS function of SAS (SAS Institute Inc., Cary, NC).

${ }^{2}$ Treatments were the CON group assigned to a dry period of $57 \mathrm{~d}(\mathrm{SD}=5.9 \mathrm{~d})$ and the SDP group assigned to an SDP of $35 \mathrm{~d}(\mathrm{SD}=6.3 \mathrm{~d})$. ${ }^{3}$ The cows were classified into primiparous cows (CON: $\mathrm{n}=7$; SDP: $\left.\mathrm{n}=8\right)$ and multiparous cows $(\mathrm{CON}: \mathrm{n}=7 \mathrm{C} ; \mathrm{SDP}: \mathrm{n}=7$ ).

${ }^{4}$ Factor to represent milk yield in the previous lactation $(305 \mathrm{~d})$.

${ }^{5}$ Linear SCS.

\section{RESULTS AND DISCUSSION}

\section{Changes in DMI, BW, BCS, and BFT}

The average DMI, BW, BCS, and BFT are reported in Table 3. The relative changes in DMI, BW, BCS and BFT are illustrated in Figures 1, 2, 3 and 4, respectively.

Average DMI of the cows assigned to a SDP and fed a late-lactation diet was approximately $4.11 \mathrm{~kg} / \mathrm{cow}$ per day greater, compared with the CON group, from d -60 until calving. Postpartum DMI was not affected by the treatment. No differences existed in BW, BCS, and BFT.

The increased prepartum DMI observed in the present study could possibly have been due to the higher palatability and nutritional quality of the lactation diet compared with the dry-cow diet. Transition to TMRD at $\mathrm{d}-60$ before planned calving resulted in a pronounced decrease in the DMI of cows in the CON group. The DMI of cows in the SDP group decreased progressively until approximately $1 \mathrm{wk}$ before calving. Thus, we can hypothesize that the DMI of cows in the CON group was influenced by the switch to a dry-cow diet rich in forage with low energy concentration and lower palatability. Similar to other studies, considerable reduction in DMI in the last week before parturition (Bertics et al., 1992; Weber et al., 2013) was observed in both groups. Also in accordance with other studies, the highest DMI in both groups was observed after the peak of lactation (Ingvartsen and Andersen, 2000; Weber et al., 2013). The prepartum DMI of cows assigned to SDP was not altered in 2 out of 3 studies (Gulay et al., 2003; Jolicoeur et al., 2010). One study (Rastani et al., 2005) reported an increase. In contrast to our results, Jolicoeur et al. (2010) observed an increase in postpartum DMI, and both Gulay et al. (2003) and Rastani et al. (2005) observed a numerical increase in feed intake postpartum when the dry period was reduced from 8 to $4 \mathrm{wk}(P>0.05)$. These results suggest that DMI is influenced by more factors than simply the length of the dry period. Lower DMI can be possibly influenced by fat mobilization (Dann et al., 2006; Weber et al., 2013). Feeding postcalving cows a high-energy diet could increase DMI and milk yield and improve the energy status of cows compared with animals fed a low-energy diet (Law et al., 2011).

Care should be taken when the condition of cows is evaluated. Body weight is of limited relevance for the estimation of body fat mobilization because the portion of body fat relative to BW change varies greatly, depending on age (Klawuhn and Staufenbiel, 


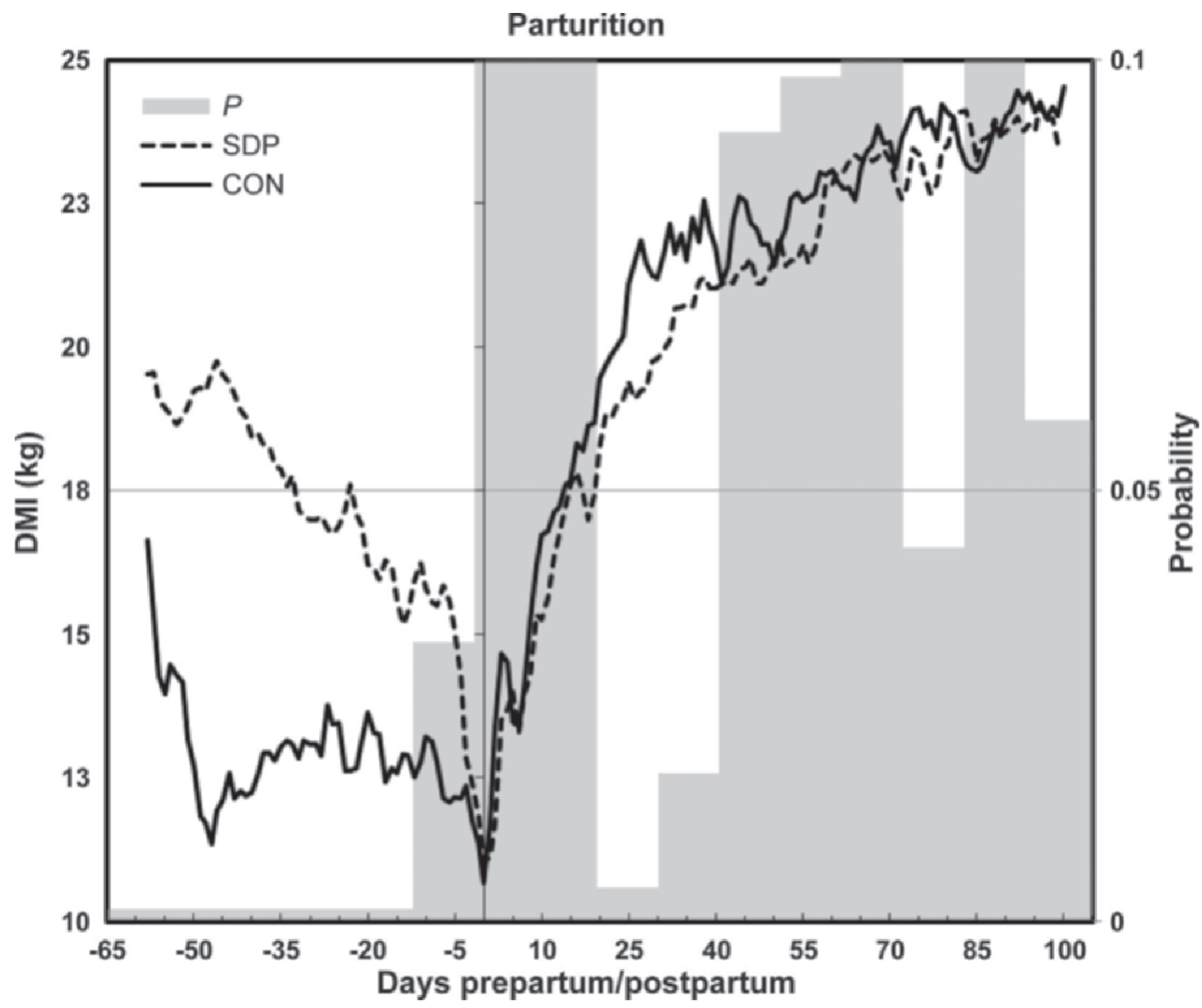

Figure 1. Relative changes in DMI from $-60 \mathrm{~d}$ prepartum to 100 DIM in cows assigned to a conventional (control, CON) or shortened dry period (SDP). The $P$-values for the selected dates were calculated in intervals of $10 \mathrm{~d}$.

1997), and is influenced by DMI and time since last feeding (Schröder and Staufenbiel, 2006). In addition, the frame size of the animal must be considered. Body condition score is a subjective measure and depends on the judgment of the assessor. Back-fat thickness is likely a more objective and precise measure. According to Klawuhn and Staufenbiel (1997), a change in BFT of $1 \mathrm{~mm}$ corresponded to a gain or loss of approximately $5 \mathrm{~kg}$ of body fat. The prepartum BCS (3.58) of cows in the present study corresponded with the BCS recommended in the literature (Hutjens, 1996; Al Ibrahim et al., 2010). Overall, those authors suggested that an ideal BCS near calving is from 3 to 3.5 to stimulate DMI and alleviate the magnitude of NEB in early lactation. To achieve optimal BCS before calving, some authors (Contreras et al., 2002) has suggested managing cows to achieve a BCS of approximately 3.0 rather than the traditional 3.5 to 3.75 at dry-off, particularly because cows with high BCS, BFT, and BHBA concentrations showed the lowest DMI already before calving (Hayirli et al., 2002; Weber et al., 2013). Similar to our results, recent research (Santschi et al., 2011a; Soleimani et al.,
2012) did not detect any effect of dry period length (60 vs. $35 \mathrm{~d}$ ) on the BW or BCS of the cows. In contrast, Weber et al. (2013) observed that BW was affected ( $P$ $<0.05$ ) by dry period length during their entire study.

\section{Concentrations of Colostrum Immunoglobulins and BiW of Calves}

The least squares means for the concentrations of colostrum IgG and $\mathrm{BiW}$ of calves of cows assigned to the conventional dry period or SDP are shown in Table 3. The concentration of IgG ranged from 52 to $90 \mathrm{~g} / \mathrm{L}$ (average $\pm \mathrm{SD}=73 \pm 14.16 \mathrm{~g} / \mathrm{L}$ ) for the CON group and from 55 to $105 \mathrm{~g} / \mathrm{L}$ (average $\pm \mathrm{SD}=$ $80 \pm 15.94 \mathrm{~g} / \mathrm{L})$ for the SDP group $(P>0.05)$. The average $( \pm \mathrm{SD}) \mathrm{BiW}$ of calves were $44.69 \pm 4.33 \mathrm{~kg}$ for CON and $44.08 \pm 4.06 \mathrm{~kg}$ for SDP calves $(P>0.05)$. Eight bullocks and 5 heifers were born in the CON group and 7 bullocks and 5 heifers were born in the SDP group. Stillborn calves and twins were excluded from the statistical analysis of $\mathrm{BiW}$. Two calves were stillborn in the SDP group, and 1 was from twins. 


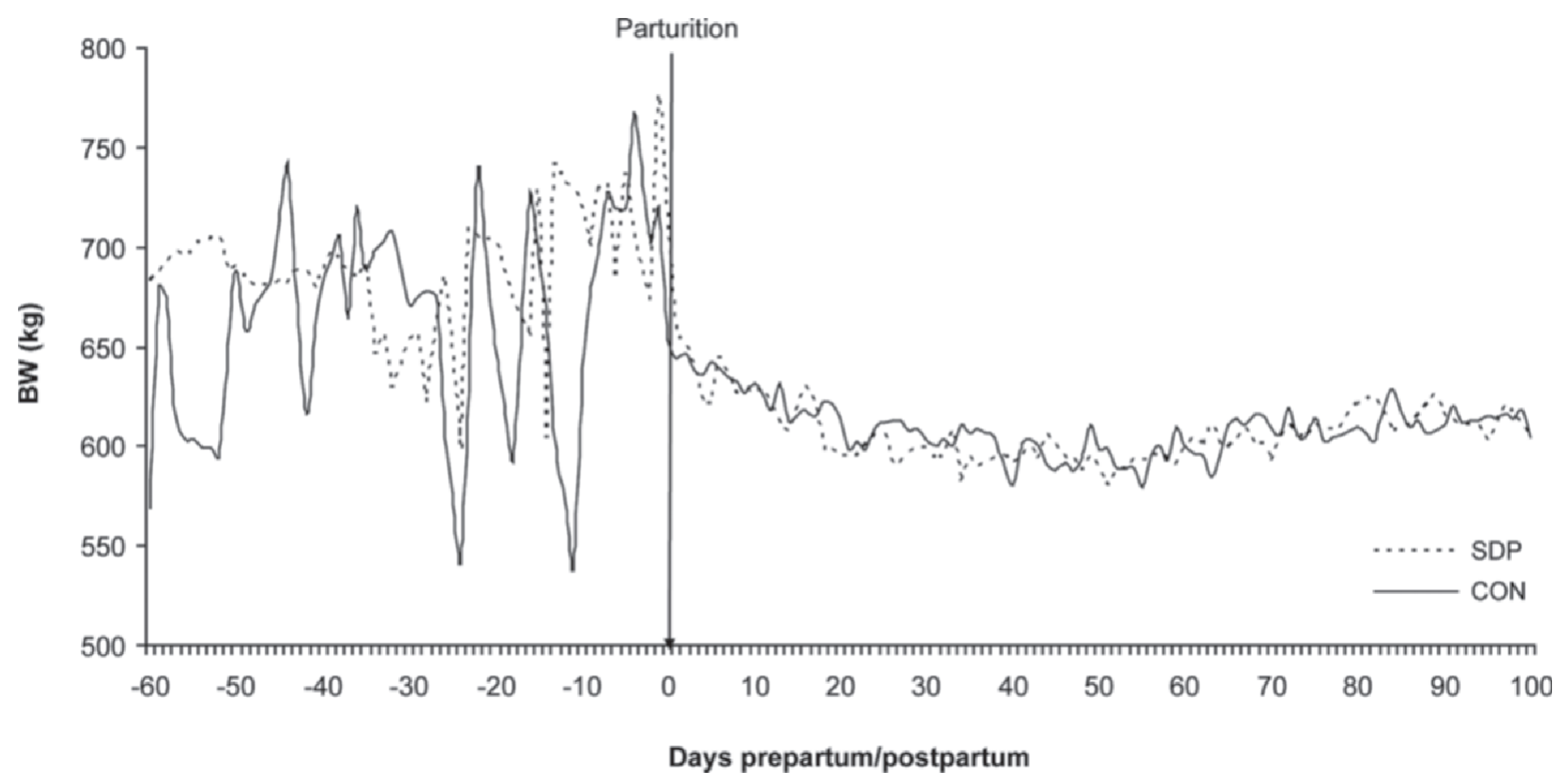

Figure 2. Relative changes in BW from $-60 \mathrm{~d}$ prepartum to $100 \mathrm{DIM}$ in cows assigned to a conventional (control, CON) or shortened dry period (SDP). Intervals were $10 \mathrm{~d}$. No significant differences existed between the groups $(P>0.05)$.

There was 1 set of twins in the CON group and 2 sets of twins in the SDP group.

Data on the relationship of dry period management and calf vitality, growth, and health are lacking in the literature. Similar to our results, shortening of the dry period has not been shown to affect colostrum quality (Rastani et al., 2005; Watters et al., 2008) or calf BiW (Gulay et al., 2005; Rastani et al., 2005; Pezeshki et al.,

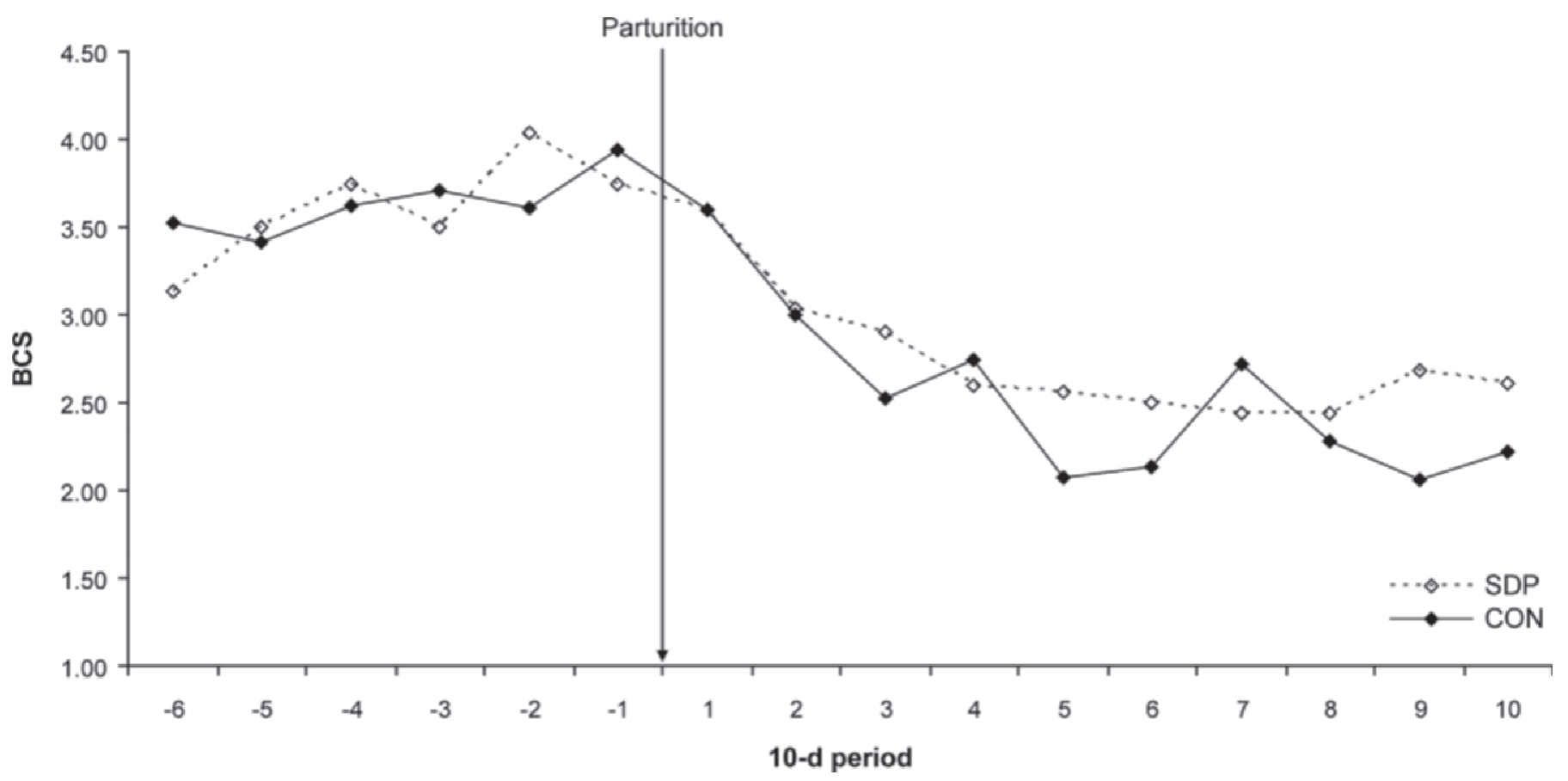

Figure 3. Relative changes in BCS from $-60 \mathrm{~d}$ prepartum to 100 DIM in cows assigned to a conventional (control, CON) or shortened dry period (SDP). Intervals were $10 \mathrm{~d}$. No significant differences existed between the groups $(P>0.05)$. 


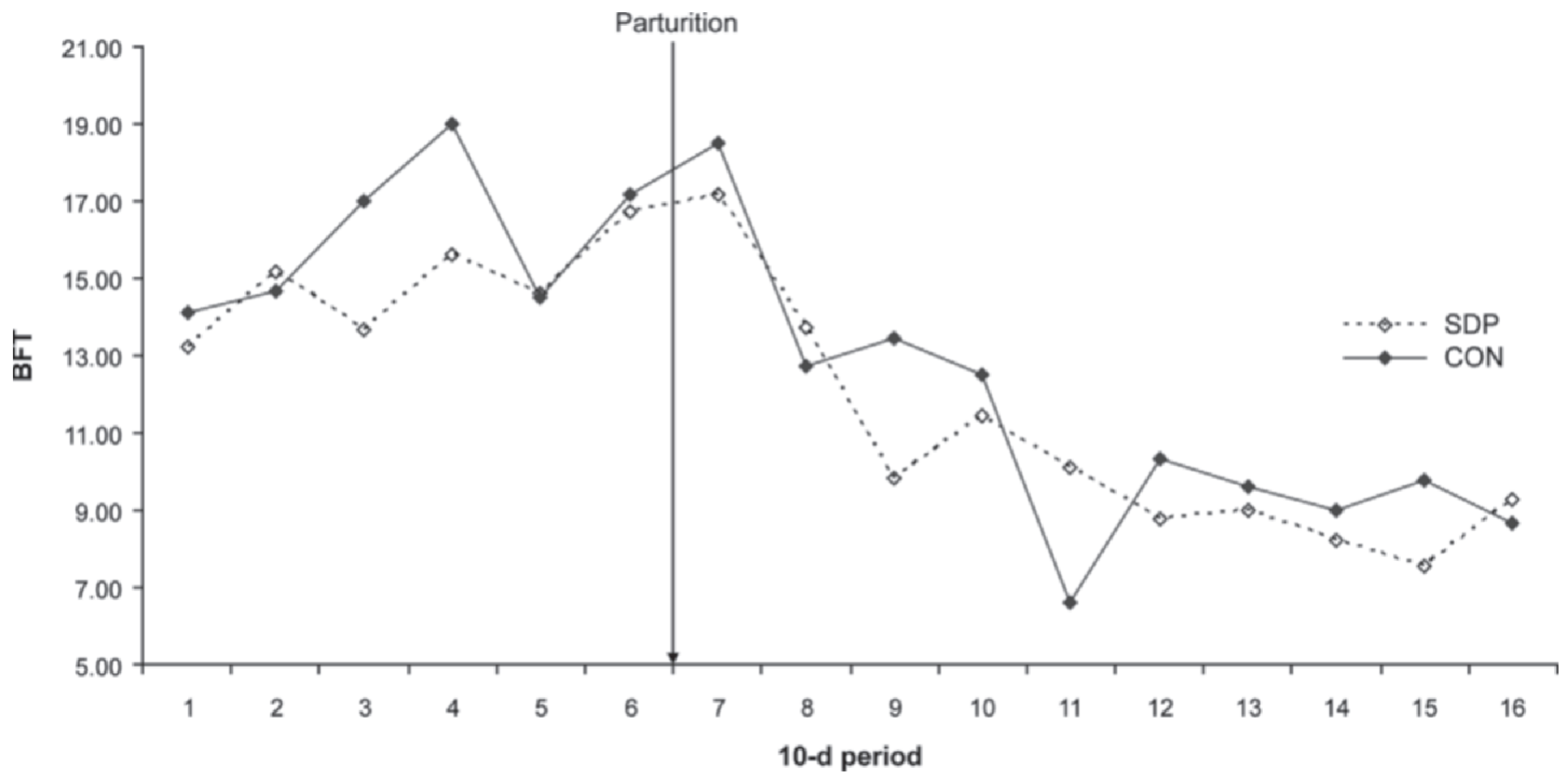

Figure 4. Relative changes in back fat thickness (BFT) trough $-60 \mathrm{~d}$ prepartum to $100 \mathrm{DIM}$ in cows assigned to a conventional (con, CON) or shortened dry period (SDP). Intervals were $10 \mathrm{~d}$. No significant differences existed between the groups $(P>0.05)$.

2008). Decreased IgG concentration in colostrum has been observed in continuously milked cows (Annen et al., 2004; Rastani et al., 2005; Klusmeyer et al., 2009). Smaller calf BiW was associated with a 51 to 60 -d dry period compared with longer dry periods (Atashi et al., 2013). Fetal growth and calf $\mathrm{BiW}$ is also affected by maternal diet (Wu et al., 2006). As reviewed by Funston et al. (2010), increased global nutrient supply throughout gestation as well as increased protein supplementation of dams in late gestation increased calf BiW (Larson et al., 2009).

\section{Milk Production}

Additional prepartum milk production from cows assigned to the SDP was $15.60 \pm 1.65 \mathrm{~kg}$ milk/cow per day. The prepartum milk contained $4.59 \%$ fat and $3.98 \%$ protein. Hence, cows with an SDP produced approximately $390 \mathrm{~kg}$ of milk during extended lactation prepartum (approximately $25 \mathrm{~d}$ ).

The production of milk, FCM, and ECM and milk composition in the first 100 DIM are reported in Table 3. The relative changes in milk fat, milk protein, lactose, and milk urea concentrations in the first 100 DIM are illustrated in Figure 5. The cows with an SDP produced approximately $2.78 \mathrm{~kg} / \mathrm{d}(6.9 \%)$ less milk in the first 100 DIM; the difference is not statistically significant. The concentration of milk protein was influenced by parity $(P<0.05)$ and by milk production in the previous lactation $(P<0.001)$. The effect of the previous lactation on the production of milk, FCM and ECM was also very high $(P<0.0001)$. If the milk production in the previous lactation was higher than $100 \mathrm{~kg}$, the value of milk production in next lactation increases by $2 \pm 0.4 \mathrm{~kg}$. No significant differences existed in mean concentrations of milk fat, protein, lactose, and milk urea. The treatment did not affect SCC in milk. But we observed 3 cows with chronic and recurring mastitis in the CON group.

The relative changes in milk yields through standardized lactation $(305 \mathrm{~d})$ are illustrated in Figure 6 (milk control data). Average milk productions through standardized lactation were $34.7 \pm 1.3 \mathrm{~kg}(\mathrm{CON})$ and $31.6 \pm 1.3 \mathrm{~kg}(\mathrm{SDP} ; P=0.099)$. Hence, the total milk production values for $305 \mathrm{~d}$ were $10,583 \mathrm{~kg}(\mathrm{CON})$ and $9,638 \mathrm{~kg}$ (SDP). The lactation curve of cows with SDP was flatter.

Previous studies (e.g., Klusmeyer et al., 2009; Soleimani et al., 2010; Safa et al., 2013) have shown that reducing the dry period length decreases milk yield in the subsequent lactation. This has been also confirmed by retrospective studies (Atashi et al., 2013; Ghavi Hossein-Zadeh and Mohit, 2013; Steeneveld et al., 2013). Additionally, in Gulay et al. (2005), the relative contribution of udder halves dry for $30 \mathrm{~d}$ to the total daily milk yield was reduced by $9.8 \%$ compared with 


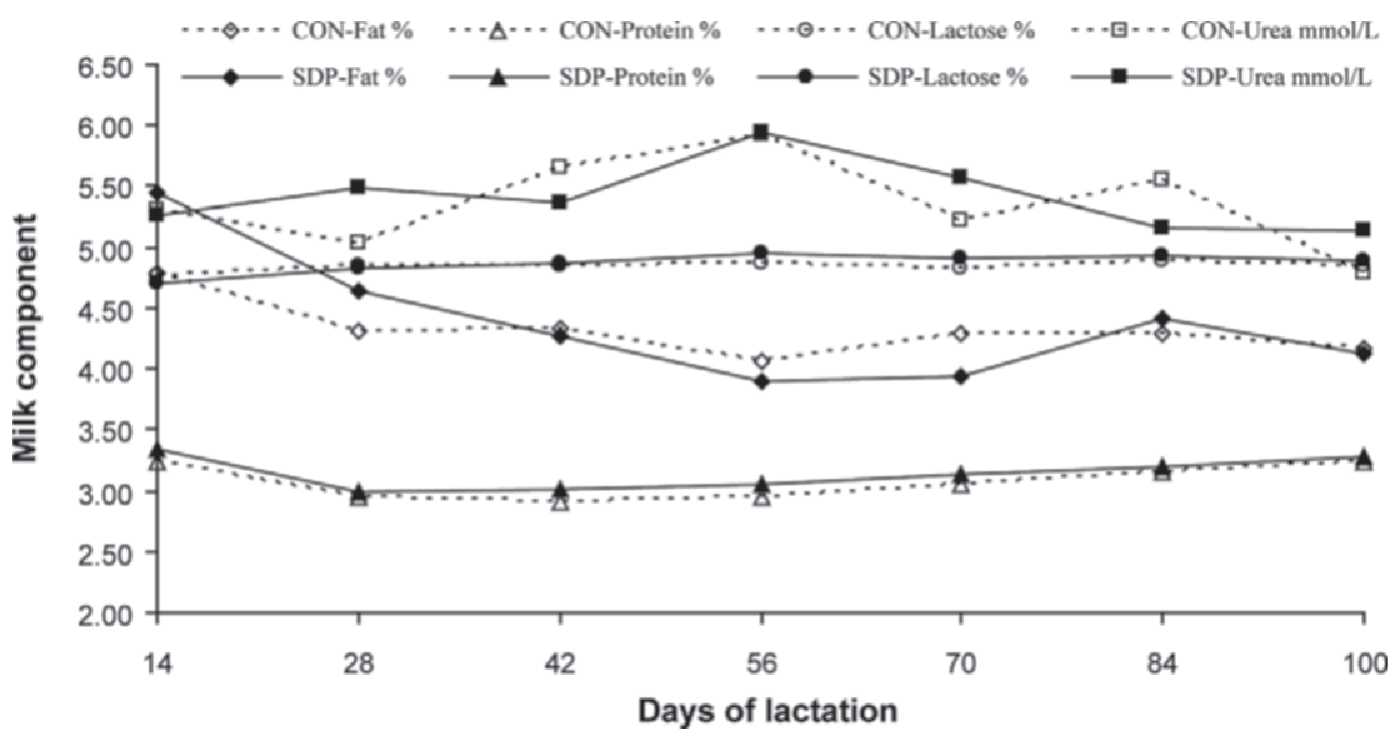

Figure 5. Relative changes in milk fat, milk protein, lactose, and urea concentrations in the first 100 DIM in cows assigned to a conventional (control, CON) or shortened dry period (SDP). The values were calculated as the average per group (SDP or CON) at selected sampling days (i.e., 14, 28, 42, 56, 70, 84, and $100 \mathrm{~d}$ postpartum). No significant differences existed between the groups $(P>0.05)$.

70-d dried udder halves through 100 DIM $(P=0.03) . \quad 3 \%$ compared with a dry period of 65 d. Soleimani et al. In contrast, Jolicoeur et al. (2010) reported that short- (2012) reported no effect of an SDP on milk yield in the ening the dry period to $35 \mathrm{~d}$ increased the milk yield by first $60 \mathrm{~d}$ postpartum. Based on previous observations,

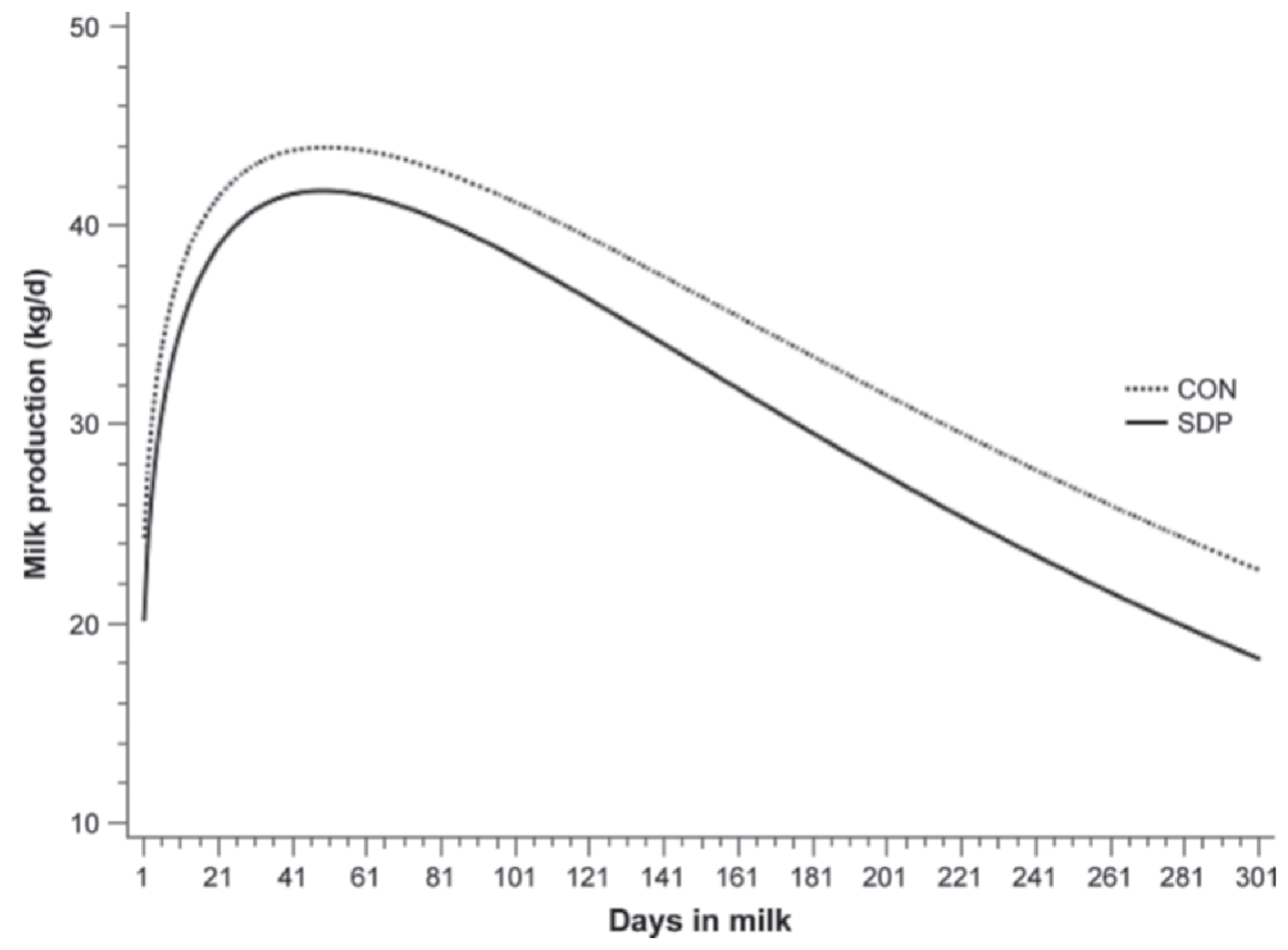

Figure 6. Relative changes of milk yields through standardized lactation (305 d) in cows assigned to a conventional (control, CON) or shortened dry period (SDP). No significant differences existed between the groups $(P>0.05)$. 
various reasons exist for a decreased milk yield due to an SDP. Schröder and Staufenbiel (2006) concluded that a change in BCS during the first month of lactation has a stronger influence on milk yield than BCS at parturition. Thus, thinner cows produced more milk (Garnsworthy and Topps, 1982; Domecq et al., 1997). In contrast, excessive lipolysis has been associated with the increased incidence of health disorders (e.g., fatty liver, ketosis, milk fever, and displaced abomasum), resulting in reduced milk yield (Grummer, 1993; Waltner et al., 1993; Rukkwamsuk et al., 1999). As previous studies have focused mainly on limited lactation in the postcalving period (e.g., 100 DIM), it is difficult to evaluate the lactation persistency of cows with SDP. Mantovani et al. (2010a) reported that continuously milked cows produced approximately $5.5 \mathrm{~kg} / \mathrm{d}$ less milk and reached the peak of lactation $10 \mathrm{~d}$ earlier than cows assigned a traditional dry-off period of $55 \mathrm{~d}$. Gulay et al. (2003) concluded that a dry period of $30 \mathrm{~d}$ is sufficient to sustain milk yield. However, other studies (Pezeshki et al., 2007; Watters et al., 2008; Santschi et al., 2011a) reported a significant reduction in milk yield for second-lactation cows assigned to SDP, whereas milk yields from cows in their third-or-greater lactation were not affected. These results suggest that young cows (parity 2) are more susceptible to a reduction in dry days compared with older cows (parity $\geq 3$ ). This hypothesis has been confirmed in a retrospective study by Kuhn et al. (2006). Based upon these observations, we could speculate that the greater milk production of cows assigned to a conventional dry period was due to the higher numbers of active and functional mammary cells compared with cows with SDP (Capuco et al., 1997; Gulay et al., 2005). Despite the milk loss observed in cows with reduced dry periods, studies by Annen et al. (2004), Andersen et al. (2005), and Rastani et al. (2005) monitored milk yield during a limited period postcalving and reported that the additional precalving milk yield compensated for the reduced milk yield at the beginning of the subsequent lactation $(7,10$, and 17 wk, respectively). To our knowledge, previous studies did not report milk protein and fat composition or the quality of the additional milk produced precalving, which are important when considering the market value of the additional prepartum milk. As concentrations of milk components are negatively correlated with milk yield, the percentages of milk protein and milk fat could increase in late lactation (Rémond et al., 1992; Rémond and Bonnefoy, 1997; Mantovani et al., 2010a). Several studies have also indicated that reducing the dry period has a positive effect on milk composition in early lactation. For example, Gulay et al. (2003), Watters et al. (2008), and Soleimani et al. (2010) reported that milk protein content increased an average of $0.12 \%$ and was accompanied by minor or no changes in milk fat content. The reported increase in milk protein content could be attributable to an improved postpartum energy balance of cows with a reduced dry period and, thus, sparing of amino acids and energy for protein synthesis (Coulon and Rémond, 1991; Rémond et al., 1992; Weber et al., 2013). Gulay et al. (2003), Annen et al. (2004), and Klusmeyer et al. (2009) noted lower SCC for cows with reduced dry periods. As the majority of mastitis cases originate during the dry period (Green et al., 2008; Collier et al., 2012), the incidence of mastitis could be lower for cows with a reduced dry period. Overall, previous studies found no effect of dry period length on mastitis incidence (Church et al., 2008; Watters et al., 2008; Santschi et al., 2011b). A recent study by Steeneveld et al. (2013) found no effect of dry period length on postpartum SCC.

\section{Concentrations of Plasma Metabolites and Parameters of Rumen Fluid}

The least squares means for the concentrations of blood plasma metabolites from the $\mathrm{d}-60$ before expected calving to 100 DIM are recoded in Table 4 . No differences were detected in plasma concentrations of glucose, total protein, albumin, BHBA, NEFA, triacylglycerol, and cholesterol and the activity of $\gamma$-glutamyltransferase $(P>0.05)$. The postpartum concentration of plasma urea was higher in the SDP group compared with the CON group $(P<0.05)$ and postpartum concentrations of total bilirubin were higher in the CON group compared with the SDP group $(P<0.05)$. The activity of aspartate aminotransferase postpartum was greater in the CON group compared with the SDP group $(P<0.001)$. The effect of parity was significant only for prepartum concentration of BHBA $(P<0.01)$. This single significance could be a matter of chance. Most previous studies (e.g., Rastani et al., 2005; Pezeshki et al., 2007; Soleimani et al., 2012) found no effect of shortening the dry period to shorter than $40 \mathrm{~d}$ on basic parameters of blood, such as concentrations of glucose, BHBA, and NEFA. Watters et al. (2008), Klusmeyer et al. (2009), and Safa et al. (2013) observed decreased concentrations of BHBA and NEFA after calving for cows with SDP compared with cows given the traditional dry period of about $60 \mathrm{~d}$. As reviewed by Pezeshki et al. (2010), continuously milked cows have lower concentrations of BHBA and better energy status in the subsequent lactation.

Obtained parameters of rumen fluid are recorded in Table 5. Prepartum concentrations of lactic acid, acetic acid, propionic acid, and butyric acid and, hence, concentrations of total VFA were higher in rumen fluid of cows of the SDP group compared with the CON group. 
Table 4. Least squares means for prepartum and postpartum plasma metabolite concentrations

\begin{tabular}{|c|c|c|c|c|c|}
\hline Parameter $^{1}$ & Period & $\begin{array}{c}\text { Mean } \\
\mathrm{CON} \pm \mathrm{SE}^{2}\end{array}$ & $\begin{array}{c}\text { Mean } \\
\mathrm{SDP} \pm \mathrm{SE}^{3}\end{array}$ & $\underset{P \text {-value }}{\text { Group }}$ & $\begin{array}{l}\text { Parity } \\
P \text {-value }\end{array}$ \\
\hline \multirow[t]{2}{*}{ Total protein $(\mathrm{g} / \mathrm{L})$} & Prepartum & $71.79 \pm 0.49$ & $72.21 \pm 0.45$ & $>0.05$ & $>0.05$ \\
\hline & Postpartum & $73.37 \pm 0.35$ & $73.09 \pm 0.44$ & $>0.05$ & $>0.05$ \\
\hline \multirow[t]{2}{*}{ Albumin (g/L) } & Prepartum & $33.22 \pm 0.23$ & $33.15 \pm 0.21$ & $>0.05$ & $>0.05$ \\
\hline & Postpartum & $33.39 \pm 0.19$ & $33.08 \pm 0.25$ & $>0.05$ & $>0.05$ \\
\hline \multirow[t]{2}{*}{ Glucose (mmol/L) } & Prepartum & $3.43 \pm 0.03$ & $3.43 \pm 0.02$ & $>0.05$ & $>0.05$ \\
\hline & Postpartum & $3.06 \pm 0.04$ & $3.05 \pm 0.04$ & $>0.05$ & $>0.05$ \\
\hline \multirow[t]{2}{*}{ Urea $(\mathrm{mmol} / \mathrm{L})$} & Prepartum & $4.01 \pm 0.05$ & $3.97 \pm 0.06$ & $>0.05$ & $>0.05$ \\
\hline & Postpartum & $5.20 \pm 0.09$ & $5.43 \pm 0.04$ & $<0.05$ & $>0.05$ \\
\hline \multirow[t]{2}{*}{ NEFA $(\mathrm{mmol} / \mathrm{L})$} & Prepartum & $0.22 \pm 0.01$ & $0.22 \pm 0.01$ & $>0.05$ & $>0.05$ \\
\hline & Postpartum & $0.46 \pm 0.03$ & $0.50 \pm 0.04$ & $>0.05$ & $>0.05$ \\
\hline \multirow[t]{2}{*}{$\mathrm{BHBA}(\mathrm{mmol} / \mathrm{L})$} & Prepartum & $0.43 \pm 0.01$ & $0.39 \pm 0.01$ & $>0.05$ & $>0.05$ \\
\hline & Postpartum & $0.73 \pm 0.03$ & $0.79 \pm 0.07$ & $>0.05$ & $<0.01$ \\
\hline \multirow[t]{2}{*}{ TAG (mmol/L) } & Prepartum & $0.21 \pm 0.01$ & $0.21 \pm 0.01$ & $>0.05$ & $>0.05$ \\
\hline & Postpartum & $0.34 \pm 0.02$ & $0.34 \pm 0.01$ & $>0.05$ & $>0.05$ \\
\hline \multirow[t]{2}{*}{ Cholesterol $(\mathrm{mmol} / \mathrm{L})$} & Prepartum & $3.59 \pm 0.07$ & $3.53 \pm 0.06$ & $>0.05$ & $>0.05$ \\
\hline & Postpartum & $3.70 \pm 0.10$ & $3.60 \pm 0.08$ & $>0.05$ & $>0.05$ \\
\hline \multirow[t]{2}{*}{ Bilirubin $(\mathrm{mol} / \mathrm{L})$} & Prepartum & $3.69 \pm 0.07$ & $3.53 \pm 0.05$ & 0.05 & $>0.05$ \\
\hline & Postpartum & $4.52 \pm 0.13$ & $4.21 \pm 0.07$ & $<0.05$ & $>0.05$ \\
\hline \multirow[t]{2}{*}{$\mathrm{AST}(\mathrm{kat} / \mathrm{L})$} & Prepartum & $1.41 \pm 0.01$ & $1.40 \pm 0.00$ & $>0.05$ & $>0.05$ \\
\hline & Postpartum & $1.60 \pm 0.02$ & $1.52 \pm 0.01$ & $<0.001$ & $>0.05$ \\
\hline \multirow[t]{2}{*}{ GGT (kat/L) } & Prepartum & $0.25 \pm 0.01$ & $0.25 \pm 0.01$ & $>0.05$ & $>0.05$ \\
\hline & Postpartum & $0.42 \pm 0.02$ & $0.38 \pm 0.01$ & $>0.05$ & $>0.05$ \\
\hline \multirow[t]{2}{*}{$\mathrm{Ca}(\mathrm{mmol} / \mathrm{L})$} & Prepartum & $2.42 \pm 0.03$ & $2.46 \pm 0.02$ & $>0.05$ & $>0.05$ \\
\hline & Postpartum & $2.25 \pm 0.02$ & $2.32 \pm 0.03$ & $>0.05$ & $>0.05$ \\
\hline \multirow[t]{2}{*}{$\mathrm{P}(\mathrm{mmol} / \mathrm{L})$} & Prepartum & $2.12 \pm 0.06$ & $2.06 \pm 0.05$ & $>0.05$ & $>0.05$ \\
\hline & Postpartum & $2.01 \pm 0.03$ & $2.03 \pm 0.02$ & $>0.05$ & $>0.05$ \\
\hline \multirow{2}{*}{$\mathrm{Mg}(\mathrm{mmol} / \mathrm{L})$} & Prepartum & $1.20 \pm 0.21$ & $1.17 \pm 0.02$ & $>0.05$ & $>0.05$ \\
\hline & Postpartum & $0.97 \pm 0.01$ & $0.98 \pm 0.01$ & $>0.05$ & $>0.05$ \\
\hline
\end{tabular}

${ }^{1}$ TAG $=$ triacylglycerol; AST $=$ aspartate aminotransferase; GGT $=\gamma$-glutamyltransferase.

${ }^{2} \mathrm{CON}=$ control.

${ }^{3} \mathrm{SDP}=$ shortened dry period.

${ }^{4}$ Treatments were the CON group assigned to a dry period of $57 \mathrm{~d}(\mathrm{SD}=5.9 \mathrm{~d})$ and the SDP group assigned to an SDP of $35 \mathrm{~d}(\mathrm{SD}=6.3 \mathrm{~d})$.

${ }^{5}$ The cows were classified into primiparous cows (CON: $\mathrm{n}=7 ;$ SDP: $\left.\mathrm{n}=8\right)$ and multiparous cows $(\mathrm{CON}: \mathrm{n}=$ 7; SDP: $\mathrm{n}=7$ ).

Thus, mean $\mathrm{pH}$ of the rumen fluid of cows in the SDP group prepartum was lower compared with the CON group. This could be result of feeding a different type of diet richer in concentrates in the SDP group (TMR2) versus the CON group (TMRD). Postpartum concentrations of VFA and $\mathrm{NH}_{3}$ and the $\mathrm{pH}$ of rumen fluid did not differ between the groups. After calving, both groups were fed the same lactation diet corresponding to their lactation requirements (see Tables 1 and $2)$. Data on the effect of dry period length on rumen parameters and health in the literature are scarce.

\section{CONCLUSIONS}

The prepartum DMI of cows assigned to an SDP of approximately $35 \mathrm{~d}$ and fed a late-lactation diet was approximately $4.11 \mathrm{~kg} / \mathrm{cow}$ per day greater compared with the CON cows assigned to a conventional dry period of $60 \mathrm{~d}$ and fed a dry-cow diet. No effect of dry period strategy on postpartum DMI was detected. Greater prepartum DMI of cows in the SDP group could be the result of feeding a late-lactation diet during this period. The BW, BCS, BFT, colostrum IgG concentration, and calf BiW were not affected by treatment. Similarly the treatment did not affect milk production of the cows. The effect of milk production on previous lactation strongly influenced production of milk, FCM, ECM, and concentrations of milk protein in next lactation. Milk protein concentrations were lower in primiparous cows. High concentrations of milk fat and milk urea, and low concentrations of milk protein and BCS $<3$, which could indicate an NEB in cows in early lactation, were observed in both groups. The basic parameters of blood plasma such as concentrations of glucose, BHBA, and NEFA were not affected by the treatment. The activity of aspartate aminotransferase postpartum was greater in CON cows with a conventional dry period of $60 \mathrm{~d}$ compared with the SDP group. Shortening the dry period to $35 \mathrm{~d}$ and feeding a late-lactation diet prepartum increased the production of lactic acid, acetic acid, propionic acid, butyric acid, and total VFA and decreased the rumen $\mathrm{pH}$. Postpartum concentrations 
Table 5. Least squares means for prepartum and postpartum concentrations of VFA and ammonium and $\mathrm{pH}$ of the rumen fluid

\begin{tabular}{|c|c|c|c|c|c|}
\hline Parameter & Period & $\begin{array}{c}\text { Mean } \\
\mathrm{CON} \pm \mathrm{SE}^{1}\end{array}$ & $\begin{array}{c}\text { Mean } \\
\mathrm{SDP} \pm \mathrm{SE}^{2}\end{array}$ & $\underset{P \text {-value }}{\text { Group }}$ & $\begin{array}{c}\text { Parity } \\
P \text {-value }\end{array}$ \\
\hline \multirow[t]{2}{*}{ Lactic acid (mmol/L) } & Prepartum & $0.28 \pm 0.03$ & $0.49 \pm 0.03$ & $3.2 \mathrm{E}-05$ & $>0.05$ \\
\hline & Postpartum & $0.60 \pm 0.04$ & $0.57 \pm 0.04$ & $>0.05$ & $>0.05$ \\
\hline \multirow[t]{2}{*}{ Acetic acid (mmol/L) } & Prepartum & $63.52 \pm 2.12$ & $72.05 \pm 1.23$ & $<0.01$ & $>0.05$ \\
\hline & Postpartum & $78.08 \pm 1.34$ & $76.54 \pm 1.30$ & $>0.05$ & $>0.05$ \\
\hline \multirow[t]{2}{*}{ Propionic acid $(\mathrm{mmol} / \mathrm{L})$} & Prepartum & $18.84 \pm 0.76$ & $21.10 \pm 0.45$ & 0.01 & $>0.05$ \\
\hline & Postpartum & $23.47 \pm 0.67$ & $22.41 \pm 0.68$ & $>0.05$ & $>0.05$ \\
\hline \multirow{2}{*}{ Butyric acid (mmol/L) } & Prepartum & $12.94 \pm 0.73$ & $15.44 \pm 0.39$ & $<0.01$ & $>0.05$ \\
\hline & Postpartum & $16.94 \pm 0.44$ & $16.78 \pm 0.52$ & $>0.05$ & $>0.05$ \\
\hline \multirow[t]{2}{*}{ Valeric acid (mmol/L) } & Prepartum & $0.33 \pm 0.04$ & $0.42 \pm 0.03$ & $>0.05$ & $>0.05$ \\
\hline & Postpartum & $0.51 \pm 0.04$ & $0.49 \pm 0.04$ & $>0.05$ & $>0.05$ \\
\hline \multirow[t]{2}{*}{ Total VFA (mmol/L) } & Prepartum & $95.91 \pm 3.36$ & $109.50 \pm 1.84$ & 0.001 & $>0.05$ \\
\hline & Postpartum & $119.18 \pm 2.30$ & $116.79 \pm 2.40$ & $>0.05$ & $>0.05$ \\
\hline \multirow[t]{2}{*}{$\mathrm{pH}$} & Prepartum & $6.97 \pm 0.04$ & $6.73 \pm 0.04$ & $<0.001$ & $>0.05$ \\
\hline & Postpartum & $6.43 \pm 0.06$ & $6.55 \pm 0.07$ & $>0.05$ & $>0.05$ \\
\hline \multirow{2}{*}{$\mathrm{NH}_{3}(\mathrm{mg}$ of $\mathrm{N} / 100 \mathrm{~g})$} & Prepartum & $15.95 \pm 0.49$ & $16.01 \pm 0.62$ & $>0.05$ & $>0.05$ \\
\hline & Postpartum & $21.12 \pm 1.42$ & $18.55 \pm 1.09$ & $>0.05$ & $>0.05$ \\
\hline
\end{tabular}

${ }^{1} \mathrm{CON}=$ control.

${ }^{2} \mathrm{SDP}=$ shortened dry period.

${ }^{3}$ Treatments were: the CON group assigned to a dry period of $57 \mathrm{~d}(\mathrm{SD}=5.9 \mathrm{~d})$ and the SDP group assigned to an SDP of $35 \mathrm{~d}(\mathrm{SD}=6.3 \mathrm{~d})$

${ }^{4}$ The cows were classified into primiparous cows (CON: $\mathrm{n}=7 ;$ SDP: $\left.\mathrm{n}=8\right)$ and multiparous cows $(\mathrm{CON}: \mathrm{n}=$ 7 ; SDP: $\mathrm{n}=7)$.

of lactic acid, VFA, and $\mathrm{NH}_{3}$ and $\mathrm{pH}$ did not differ between the groups of cows (SDP vs. CON) during their first 100 DIM when all cows were fed the same lactation diet responding their lactation requirements. Based on the results of this study, we could not confirm our hypothesis. In contrast, the traditional dry period management strategy appeared to be more favorable considering the DMI, milk production, and milk persistency, compared with the SDP and feeding a latelactation diet throughout the dry period.

\section{ACKNOWLEDGMENTS}

We greatly thank all of the technicians and people from the laboratory of the Institute of Animal Science (Prague Uhrineves, Czech Republic) for their assistance and help during the course of the experiment. This study was supported by the Ministry of Agriculture of the Czech Republic (Prague, Czech Republic; Project No. MZE 0002701404).

\section{REFERENCES}

Al Ibrahim, R. M., A. K. Kelly, L. O'Grady, V. P. Gath, C. McCarney, and F. J. Mulligan. 2010. The effect of body condition score at calving and supplementation with Saccharomyces cerevisiae on milk production, metabolic status, and rumen fermentation of dairy cows in early lactation. J. Dairy Sci. 93:5318-5328.

Andersen, J. B., T. G. Madsen, T. Larsen, K. L. Ingvartsen, and M. O. Nielsen. 2005. The effects of dry period versus continuous lactation on metabolic status and performance in periparturient cows. J. Dairy Sci. 88:3530-3541.
Annen, E. L., R. J. Collier, M. A. McGuire, J. L. Vicini, J. M. Ballam, and M. J. Lormore. 2004. Effect of modified dry period lengths and bovine somatotropin on yield and composition of milk from dairy cows. J. Dairy Sci. 87:3746-3761.

AOAC International. 2005. Official Methods of Analysis of AOAC International. 18th ed. AOAC International, Gaithersburg, MD.

Atashi, H., M. J. Zamiri, and M. Dadpasand. 2013. Association between dry period length and lactation performance, lactation curve, calf birth weight, and dystocia in Holstein dairy cows in Iran. J. Dairy Sci. 96:3632-3638.

Bertics, S. J., R. R. Grummer, C. Cadorniga-Valino, and E. E. Stoddard. 1992. Effect of prepartum dry matter intake on liver triglyceride concentration and early lactation. J. Dairy Sci. 75:19141922

Capuco, A. V., R. M. Akers, and J. J. Smith. 1997. Mammary growth in Holstein cows during the dry period: Quantification of nucleic acids and histology. J. Dairy Sci. 80:477-487.

Church, G. T., L. K. Fox, C. T. Gaskins, D. D. Hancock, and J. M. Gay. 2008. The effect of a shortened dry period on intramammary infections during the subsequent lactation. J. Dairy Sci. 91:4219-4225

Collier, R. J., E. L. Annen-Dawson, and A. Pezeshki. 2012. Effects of continuous lactation and short dry periods on mammary function and animal health. Animal 6:403-414.

Contreras, L. L., C. M. Ryan, and T. R. Overton. 2002. Effects of dry cow grouping strategy and body condition score at dry off on performance of dairy cows during early lactation. J. Dairy Sci. 85(E-Suppl. 1):185. (Abstr.)

Coulon, J. B., and B. Rémond. 1991. Variations in milk output and milk protein content in response to the level of energy supply to the dairy cow: A review. Livest. Prod. Sci. 29:31-47.

Dann, H. M., N. B. Litherland, J. P. Underwood, M. Bionaz, A. D'Angelo, J. W. McFadden, and J. K. Drackley. 2006. Diets during far-off and close-up dry periods affect periparturient metabolism and lactation in multiparous cows. J. Dairy Sci. 89:3563-3577.

Degaris, P. J., I. J. Lean, A. R. Rabiee, and C. Heuer. 2008. Effects of increasing days of exposure to prepartum transition diets on milk production and milk composition in dairy cows. Aust. Vet. J. 86:341-351. 
Domecq, J. J., A. L. Skidmore, J. W. Lloyd, and J. B. Kaneene. 1997. Relationship between body condition scores and milk yield in a large dairy herd of high yielding Holstein cows. J. Dairy Sci. 80:101-112.

Edmonson, A. J., I. J. Lean, L. D. Weaver, T. Farver, and G. Webster. 1989. A body condition scoring chart for Holstein dairy cows. J. Dairy Sci. 72:68-78.

Enevoldsen, C., and J. T. Sørensen. 1992. Effects of dry period length on clinical mastitis and other major clinical health disorders. J. Dairy Sci. 75:1007-1014.

Funston, R. N., D. M. Larson, and K. A. Vonnahme. 2010. Effects of maternal nutrition on conceptus growth and offspring performance: Implications for beef cattle production. J. Anim. Sci. 88(E-Suppl. 13):205-215.

Garnsworthy, P. C., and J. H. Topps. 1982. The effect of body condition of dairy cows at calving on their food intake and performance when given complete diets. Anim. Prod. 35:113-119.

Ghavi Hossein-Zadeh, N., and A. Mohit. 2013. Effect of dry period length on the subsequent production and reproduction in Holstein cows. Span. J. Agric. Res. 11:100-108.

Green, M. J., A. J. Bradley, G. F. Medley, and W. J. Browne. 2008. Cow, farm, and herd management factors in the dry period associated with raised somatic cell counts in early lactation. J. Dairy Sci. 91:1403-1415.

Grummer, R. R. 1993. Etiology of lipid-related metabolic disorders in periparturient dairy cows. J. Dairy Sci. 76:3882-3896.

Gulay, M. S., M. J. Hayen, K. C. Bachman, T. Belloso, M. Liboni, and H. H. Head. 2003. Milk production and feed intake of Holstein cows given short (30-d) or normal (60-d) dry periods. J. Dairy Sci. 86:2030-2038.

Gulay, M. S., M. J. Hayen, H. H. Head, C. J. Wilcox, and K. C. Bachman. 2005. Milk production from Holstein half udders after concurrent thirty- and seventy-day dry periods. J. Dairy Sci. 88:3953-3962.

Hayirli, A., R. R. Grummer, E. V. Nordheim, and P. M. Crump. 2002. Animal and dietary factors affecting feed intake during the prefresh transition period in Holsteins. J. Dairy Sci. 85:3430-3443.

Hutjens, M. F. 1996. Practical approaches to feeding the high producing cow. Anim. Feed Sci. Technol. 59:199-206.

Ingvarsten, K. L., and J. B. Andersen. 2000. Integration of metabolism and intake regulation: A review focusing on periparturient animals. J. Dairy Sci. 83:1573-1597.

ISO (International Organization for Standardization). 2005. General requirements for the competence of testing and calibration laboratories. ISO 17025:2005. ISO, Geneva, Switzerland.

Jolicoeur, M., A. F. Brito, D. Pellerin, D. Lefebvre, R. Berthiaume, and C. L. Girard. 2010. Short dry period management to improve feed efficiency in early lactation. Adv. Dairy Technol. 22:388 (Abstr.)

Klawuhn, D., and R. Staufenbiel. 1997. Predictive value of back fat thickness for body fat content in cattle. Tierärztl. Prax. 25:133138. (In German).

Klusmeyer, T. H., A. C. Fitzgerald, A. C. Fabellar, J. M. Ballam, R. A. Cady, and J. L. Vicini. 2009. Effect of recombinant bovine somatotropin and a shortened or no dry period on the performance of lactating dairy cows. J. Dairy Sci. 92:5503-5511.

Kuhn, M. T., J. L. Hutchinson, and H. D. Norman. 2005. Minimum days dry to maximize milk yield in subsequent lactation. Anim. Res. 54:351-367.

Kuhn, M. T., J. L. Hutchison, and H. D. Norman. 2006. Effects of length of dry period on yields of milk fat and protein, fertility and milk somatic cell score in the subsequent lactation of dairy cows. J. Dairy Res. 73:154-162.

Larson, D. M., J. L. Martin, D. C. Adams, and R. N. Funston. 2009. Winter grazing system and supplementation during late gestation influence performance of beef cows and steer progeny. J. Anim. Sci. 87:1147-1155.

Law, R. A., F. J. Young, D. C. Patterson, D. J. Kilpatrick, A. R. Wylie, K. L. Ingvarsten, A. Hameleers, M. A. McCoy, C. S. Mayne, and C. Ferris. 2011. Effect of precalving and postcalving dietary energy level on performance and blood metabolite concentrations of dairy cows throughout lactation. J. Dairy Sci. 94:808-823.

Mantovani, R., L. Marinelli, L. Bailoni, G. Gabai, and G. Bittante. 2010a. Omission of the dry period and effects on the subsequent lactation curve and on milk quality around calving in Italian Holstein cows. Ital. J. Anim. Sci. 9:101-108.

Mantovani, R., S. Sgorlon, L. Marinelli, L. Bailoni, G. Bittante, and G. Gabai. 2010b. Oxidative stress indicators and metabolic adaptations in response to the omission of the dry period in dairy cows. J. Dairy Res. 77:273-279.

McArt, J. A. A., D. V. Nydam, and G. R. Oetzel. 2013. Dry period and parturient predictors of early lactation hyperketonemia in dairy cattle. J. Dairy Sci. 96:198-209.

NRC. 2001. Nutrient Requirements of Dairy Cattle. 7th rev. ed. Natl. Acad. Press, Washington, DC.

O’Driscoll, K., G. Olmos, S. Llamas Moya, J. F. Mee, B. Earley, D. Gleeson, B. O'Brien, and L. Boyle. 2012. A reduction in milking frequency and feed allowance improves dairy cow immune status. J. Dairy Sci. 95:1177-1187.

Pezeshki, A.. A. V. Capuco, B. De Spiegeleer, L. Peelman, M. Stevens, R. J. Collier, and C. Burvenich. 2010. An integrated view on how the management of the dry period length of lactating cows could affect mammary biology and defence. J. Anim. Physiol. Anim. Nutr. (Berl.) 94:e7-e30.

Pezeshki, A., J. Mehrzad, G. R. Ghorbani, B. De Spiegeleer, R. J. Collier, and C. Burvenich. 2008. The effect of dry period length reduction to 28 days on the performance of multiparous dairy cows in the subsequent lactation. Can. J. Anim. Sci. 88:449-456.

Pezeshki, A., J. Mehrzad, G. R. Ghorbani, H. R. Rahmani, R. J. Collier, and C. Burvenich. 2007. Effects of short dry periods on performance and metabolic status in Holstein dairy cows. J. Dairy Sci. 90:5531-5541.

Rastani, R. R., R. R. Grummer, S. J. Bertics, A. Gümen, M. C. Wiltbank, D. G. Mashek, and M. C. Schwab. 2005. Reducing dry period length to simplify feeding transition cows: Milk production, energy balance, and metabolic profiles. J. Dairy Sci. 88:1004-1014.

Rémond, B., and J. C. Bonnefoy. 1997. Performance of a herd of Holstein cows managed without the dry period. Ann. Zootech. $46: 3-12$.

Rémond, B., A. Ollier, and G. Miranda. 1992. Milking cows in late pregnancy: Milk production during this period and during the succeeding lactation. J. Dairy Res. 59:233-241.

Rukkwamsuk, T., T. A. M. Kruip, and T. Wensing. 1999. Relationship between overfeeding and overconditioning in the dry period and the problems of high producing dairy cows during the postparturient period. Vet. Q. 21:71-77.

Safa, S., A. Soleimani, and A. Heravi Moussavi. 2013. Improving productive and reproductive performance of Holstein dairy cows through dry period management. Asian-australas. J. Anim. Sci. 26:630-637.

Santschi, D. E., D. M. Lefebvre, R. I. Cue, C. L. Girard, and D. Pellerin. 2011a. Complete-lactation milk and component yields following a short (35-d) or a conventional (60-d) dry period management strategy in commercial Holstein herds. J. Dairy Sci. 94:2302-2311.

Santschi, D. E., D. M. Lefebvre, R. I. Cue, C. L. Girard, and D. Pellerin. 2011b. Incidence of metabolic disorders and reproductive performance following a short (35-d) or conventional (60-d) dry period management in commercial Holstein herds. J. Dairy Sci. 94:3322-3330.

Sawa, A., M. Bogucki, and W. Neja. 2012. Dry period length and performance of cows in the subsequent production cycle. Arch. Tierzucht 55:140-147.

Schröder, U. J., and R. Staufenbiel. 2006. Invited review: Methods to determine body fat reserves in the dairy cow with special regard to ultrasonographic measurement of backfat thickness. J. Dairy Sci. 89:1-14.

Schukken, Y. H., R. N. González, L. L. Tikofsky, H. F. Schulte, C. G. Santisteban, F. L. Welcome, G. J. Bennett, M. J. Zurakowski, and R. N. Zadoks. 2009. CNS mastitis: Nothing to worry about? Vet. Microbiol. 134:9-14. 
Soleimani, A., M. D. Mesgaran, A. H. Moussavi, A. Tahmasbi, and A. Golian. 2012. Effects of dry period length on milk yield and composition, blood metabolites, follicular dynamics and complete blood count in Holstein dairy cows. Asia Life Sci. 21:337-352.

Soleimani, A., A. H. Moussavi, M. D. Mesgaran, and A. Golian. 2010. Effects of dry period length on, milk production and composition, blood metabolites and complete blood count in subsequent lactation of Holstein dairy cows. World Acad. Sci. Eng. Technol. 68:628-633.

Sørensen, J. T., and C. Enevoldsen. 1991. Effect of dry period length on milk production in subsequent lactation. J. Dairy Sci. 74:1277-1283.

Steeneveld, W., Y. H. Schukken, A. T. M. van Knegsel, and H. Hogeveen. 2013. Effect of different dry period lengths on milk production and somatic cell count in subsequent lactations in commercial Dutch dairy herds. J. Dairy Sci. 96:2988-3001.

Waltner, S. S., J. P. McNamara, and J. K. Hillers. 1993. Relationships of body condition score to milk production variables in high producing Holstein dairy cattle. J. Dairy Sci. 76:3410-3419.

Watters, R. D., J. N. Guenther, A. E. Brickner, R. R. Rastani, P. M. Crump, P. W. Clark, and R. R. Grummer. 2008. Effects of dry period length on milk production and health of dairy cattle. J Dairy Sci. 91:2595-2603.

Weber, C., C. Hametner, A. Tuchscherer, B. Losand, E. Kanitz, W. Otten, S. P. Singh, R. M. Bruckmaier, F. Becker, W. Kanitz, and H. M. Hammon. 2013. Variation in fat mobilization during early lactation differently affects feed intake, body condition, and lipid and glucose metabolism in high-yielding dairy cows. J. Dairy Sci. 96:165-180.

Whist, A. C.. O. Østerås, and L. Sølverød. 2006. Clinical mastitis in Norwegian herds after a combined selective dry-cow therapy and teat-dipping trial. J. Dairy Sci. 89:4649-4659.

Wiedemann, S., G. Sigl, C. Schmautz, M. Kaske, E. Viturro, and H. H. D. Meyer. 2013. Omission of dry period or milking once daily affects metabolic status and is reflected by mRNA levels of enzymes in liver and muscle of dairy cows. Livest. Sci. 154:193-203.

Wu, G., F. W. Bazer, J. M. Wallace, and T. E. Spencer. 2006. BoardInvited Review: Intrauterine growth retardation: Implications for the animal sciences. J. Anim. Sci. 84:2316-2337. 